\title{
Impact of low water temperature on the development of Anguillicola crassus in the final host Anguilla anguilla
}

\author{
K. Knopi ${ }^{1, *}$, J. Würtz ${ }^{2}$, B. Sures ${ }^{1}$, H. Taraschewski ${ }^{1}$ \\ ${ }^{1}$ Zoologisches Institut - Ökologie, Universität Karlsruhe (TH), Kaiserstr. 12, D-76128 Karlsruhe, Germany \\ ${ }^{2}$ Institut für Zoologie und Limnologie, Universität Innsbruck, Technikerstr. 25, A-6020 Innsbruck, Austria
}

\begin{abstract}
The effect of low water temperatures on the development and viability of larval and adult Anguillicola crassus (Nematoda) in the final host Anguilla anguilla was studied. European eels were experimentally infected with $\mathrm{A}$. crassus and then maintained for $4 \mathrm{mo}$ at $4,9,10$ and $19^{\circ} \mathrm{C}$. Larval development showed a temperature-dependent pattern and was significantly retarded at low temperatures. Third-stage larvae survived a $4 \mathrm{mo}$ period at $4{ }^{\circ} \mathrm{C}$ without being affected, although they were not able to invade the swimbladder wall at this temperature. In contrast, adult worms were severely harmed during a 4 mo period at $4{ }^{\circ} \mathrm{C}$, as reflected by increased mortality and decreased growth and reproductivity compared to the worms maintained for the same period at $18^{\circ} \mathrm{C}$. Starvation of the eels for 4 mo at $19^{\circ} \mathrm{C}$ did not affect the development and growth of the nematode. The experimentally obtained results support the hypothesis that the spread of $A$ crassus in boreal regions, e.g. Northern Europe, is restricted by the natural ambient temperature regimes.
\end{abstract}

KEY WORDS: Eel Anguillicola crassus - Development - Temperature Starvation

\section{INTRODUCTION}

After Anguillicola crassus (Nematoda, Dracunculoidea) was imported from the Far East to Europe in the early 1980 s, it spread rapidly across the continent. Ten years after the first report of its presence in 1982 in eels from the Weser-Ems region, Germany (Neumann 1985), this parasite had become established over almost the whole of Europe (Moravec 1992). However, in southern Sweden Höglund et al. (1992) reported A. crassus populations being restricted to areas affected by thermal discharges from power stations on the Baltic coast, whereas eels from inland lakes were uninfected. These results implied that the water temperature required for a complete life-cycle of $A$. crassus is not naturally available in the areas examined.

The effect of water temperature on the hatching of Anguillicola crassus eggs and on the free-living secondstage larvae $\left(L_{2}\right)$ was extensively examined by Thomas \&

·E-mail: klaus.knopf@bio-geo.uni-karlsruhe.de
Ollevier (1993). In accordance with the findings of Kim et al. (1989, cited in Nagasawa et al. 1994) they showed that the optimum temperature for hatching lies in the range between 15 and $30^{\circ} \mathrm{C}$. At these temperatures the eggs hatch within a few days. At $10^{\circ} \mathrm{C}$ hatching is severely delayed, taking almost $1 \mathrm{mo}$, whereas at $5^{\circ} \mathrm{C}$ the $\mathrm{L}_{2}$ in the egg sheath survive but rarely emerge.

The survival of free-living $\mathrm{L}_{2}$ is also dependent on temperature. Although the published data do not correspond perfectly with each other (De Charleroy et al. 1989, Petter et al. 1990, Thomas \& Ollevier 1993), it is evident that at lower temperatures the survival time is noticeably prolonged. However, the infectivity of the $\mathrm{L}_{2}$ to the intermediate host declines with larval age (Kennedy \& Fitch 1990, Thomas \& Ollevier 1993). Kennedy \& Fitch (1990) reported $\mathrm{L}_{2}$ survival of up to $160 \mathrm{~d}$ at $10^{\circ} \mathrm{C}$. In contrast, they survive only up to $45 \mathrm{~d}$ at $23^{\circ} \mathrm{C}$ (Thomas \& Ollevier 1993).

Subsequent development in the copepod intermediate host is also affected by the water temperature. At approximately $21^{\circ} \mathrm{C}$ moulting to the third larval stage $\left(L_{3}\right)$ 

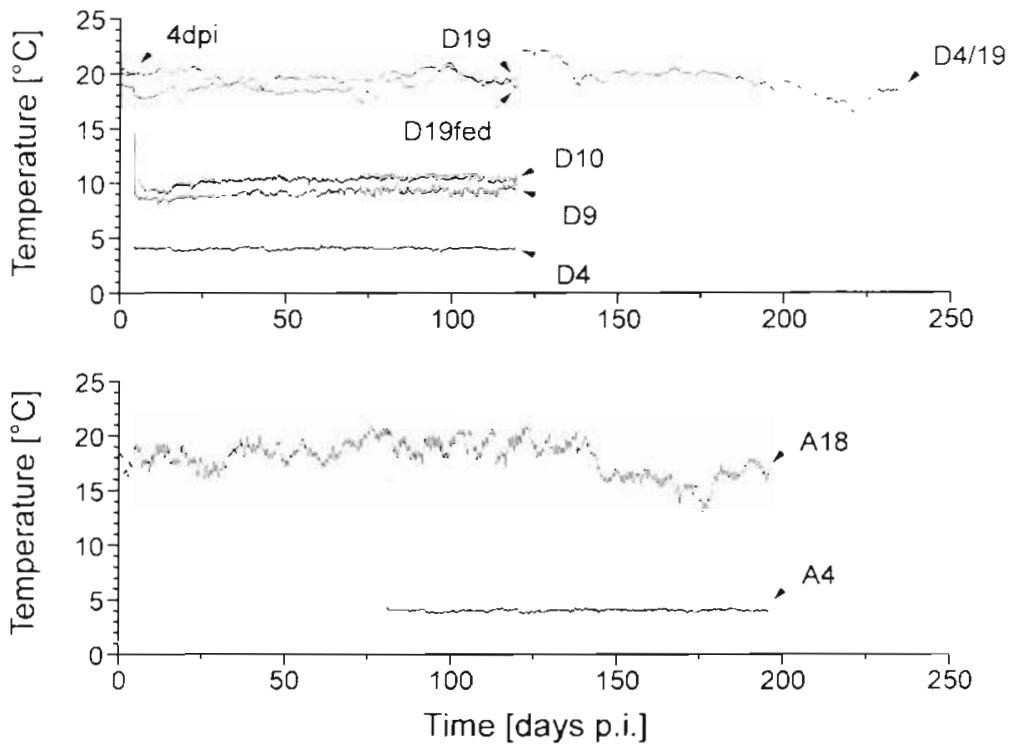

Fig. 1. Temperature regime to which eels were exposed during the experiment. Arrows indicate the times when eels of the different experimental groups (for abbreviations see Table 1) were examined. p.i.: post infection occurs between Days 10 and 13 post infection (p.i.) of the copepods (Petter et al. 1989, De Charleroy et al. 1990, Thomas \& Ollevier 1993). In contrast, the development is very slow at $12^{\circ} \mathrm{C}$ and moulting to $\mathrm{L}_{3}$ does not occur until Day 62 , whereas at higher temperatures ranging from 18 to $29^{\circ} \mathrm{C}$ the process is accelerated and first $L_{3}$ appear on Day 6 (Petter et al. 1990). Furthermore, Petter et al. (1989) demonstrated that in the (unfortunately not further specified) range from 1 to $13^{\circ} \mathrm{C}$ the $\mathrm{L}_{2}$ did not develop and even died within about 1 mo. However, the larvae were able to migrate into the haemocoel of the copepods. In consequence, Petter et al. (1989) concluded that the life-cycle of Anguillicola crassus is interrupted during the cold season and Kim et al. (1989, cited in Nagasawa et al. 1994) suggested that the nematode requires at least $15^{\circ} \mathrm{C}$ for a complete life-cycle.

However, there is a lack of information concerning the impact of temperature on Anguillicola crassus in the final host. Thus, in the present study the importance of water temperature for the invasion of the swimbladder wall by infective $L_{3}$ and their further development to mature adults via a fourth larval stage $\left(\mathrm{L}_{4}\right)$ was investigated under controlled laboratory conditions. Furthermore, the influence of low water temperatures on the viability and reproductivity of the adult worms dwelling in the swimbladder lumen of eels was studied.

\section{MATERIAL AND METHODS}

Source and maintenance of eels. European eels Anguilla anguilla weighing 60 to $80 \mathrm{~g}$ were obtained from a commercial fish farm (Limnotherm, Bergheim, Germany) known to be free of Anguillicola crassus. The eels were placed in $100 \mathrm{l}$ tanks and maintained in aerated tap water at different temperatures ranging from 4 to $20^{\circ} \mathrm{C}$ (Table 1 \& Fig. 1). The water temperature was measured and recorded hourly with a temperature logger (EBI-85, Ebro Electronexperimental period (Fig. 1).

infective larvae and iniection. Innective third-stage larvae $\left(\mathrm{L}_{3}\right)$ of Anguillicola crassus were obtained according to Haenen et al. (1994). Second-stage larvae were collected from the swimbladder lumen of naturally infected eels from the river Rhine. These larvae were fed to wild-caught planktonic copepods, mainly comprising Thermocyclops cf. crassus and Mesocyclops leuckarti, kept at $20^{\circ} \mathrm{C}$. The infective $\mathrm{L}_{3}$ were isolated $20 \mathrm{~d}$ p.i. from the intermediate hosts by the potter method described by Haenen et al. (1994) and stored in RMPI1640 medium (Sigma, Deisenhofen, Germany) containing $0.2 \%$ kanamycin at $4^{\circ} \mathrm{C}$ until application.

Prior to infection the larvae were counted in a round bottom 98-well plate and suspended in approximately $100 \mu \mathrm{l}$ RMPI-1640 medium. This suspension was administered to the eels perorally with a stomach tube (1.5 mm diameter). The wells were checked for remaining $L_{3}$ afterwards.

Experimental design. A summary of the experimental design and the number of eels of each experimental ics, Ingolstadt, Germany) during the whole

Table 1. Experimental design showing the mean \pm SD temperatures at which the different experimental groups were maintained for the times given at the top and the number of eels in each group (n). p.i.: post infection

\begin{tabular}{|c|c|c|c|c|}
\hline Group & $\mathrm{n}$ & Day 1 to 4 p.i. & \multicolumn{2}{|c|}{ Day 5 to 119 p.i. Day 120 to 234 p.i. } \\
\hline $4 d p i$ & 20 & $20.2 \pm 0.2^{\circ} \mathrm{C}$ & - & - \\
\hline D4 & 20 & $19.9 \pm 0.1^{\circ} \mathrm{C}$ & $4.0 \pm 0.1^{\circ} \mathrm{C}$ & - \\
\hline D9 & 21 & $20.2 \pm 0.2^{\circ} \mathrm{C}$ & $9.0 \pm 0.4^{\circ} \mathrm{C}$ & - \\
\hline $\mathrm{D} 10$ & 21 & $20.2 \pm 0.2^{\circ} \mathrm{C}$ & $10.2 \pm 0.5 \mathrm{C}$ & - \\
\hline D19 & 20 & $18.8 \pm 0.1^{\circ} \mathrm{C}$ & $18.8 \pm 0.7^{\circ} \mathrm{C}$ & - \\
\hline D19fed & 19 & $19.9 \pm 0.1^{\circ} \mathrm{C}$ & $19.7 \pm 0.5^{\circ} \mathrm{C}$ & - \\
\hline $\mathrm{D} 4 / 19$ & 28 & $19.9 \pm 0.1^{\circ} \mathrm{C}$ & $4.0 \pm 0.1^{\circ} \mathrm{C}$ & $19.4 \pm 1.3^{\circ} \mathrm{C}$ \\
\hline & & \multicolumn{3}{|c|}{ Day 1 to 80 p.i. Day 81 to 115 p.i. } \\
\hline A 18 & 36 & \multicolumn{2}{|c|}{$18.4 \pm 1.0^{\circ} \mathrm{C}$} & $17.7 \pm 1.8^{\circ} \mathrm{C}$ \\
\hline A4 & 46 & \multicolumn{2}{|c|}{$18.4 \pm 1.0^{\circ} \mathrm{C}$} & $4.0 \pm 0.1^{\circ} \mathrm{C}$ \\
\hline
\end{tabular}




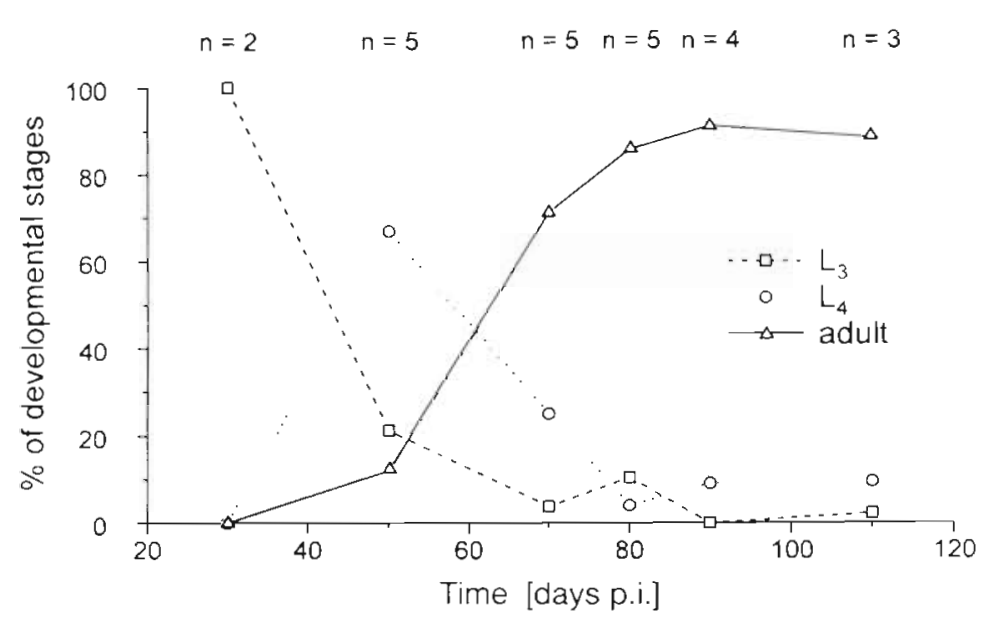

Fig. 2. Anguillicola crassus. Relative percentages of different developmental stages of the nematode out of total number of specimens recovered from the swimbladder of spot-checked Anguilla anguilla kept at $18^{\circ} \mathrm{C}$. The number of eels examined ( $\mathrm{n}$ ) is given for each spot-check

divided into 2 groups and kept for a further $115 \mathrm{~d}$ at $18^{\circ} \mathrm{C}$ (group $\mathrm{A} 18$ ) and $4^{\circ} \mathrm{C}$ (group A4), respectively. During the maintenance at $18^{\circ} \mathrm{C}$, the eels were fed in this experiment as described above.

At the end of the experiments the eels were killed and the swimbladder was examined for living and dead larvae and adults of Anguillicola crassus. As $\mathrm{L}_{3}$ and $\mathrm{L}_{4}$ cannot be distinguished from each other perfectly by means of light microscopy (Blanc et al. 1992), all larvae with a body length exceeding $1.5 \mathrm{~mm}$ were counted as $\mathrm{L}_{4}$, in accordance with the results of Blanc et al. (1992). After determining the sex of all adult worms from each eel, the male and female $A$. crassus were counted separately. Living specimens were pooled from each eel, weighed and the mean wet weight for an individual male or female was then calculated. Nematodes showing no reaction to mechanical stimula-

group is given in Table 1 . The impact of temperature on the larval development of Anguillicola crassus was examined by keeping eels infected with $20 \mathrm{~L}_{3}$ each at $4,9,10$ or $19^{\circ} \mathrm{C}$ for $115 \mathrm{~d}$ (groups D4, D9, D10 and D 19). The intermediate temperatures of 9 and $10^{\circ} \mathrm{C}$ resulted from difficulties regulating the temperature; initially, 8 and $12^{\circ} \mathrm{C}$ were intended. To determine whether the maintenance at $4^{\circ} \mathrm{C}$ (group D4) was irreversibly harmful to the larvae, another group of eels (group D4/19) was first kept at $4^{\circ} \mathrm{C}$ for $115 \mathrm{~d}$ and subsequently at $19^{\circ} \mathrm{C}$ for additional $115 \mathrm{~d}$. To allow the $\mathrm{L}_{3}$ to migrate in to the swimbladder wall, eels of all groups were kept initially at approximately $20^{\circ} \mathrm{C}$ for $4 \mathrm{~d}$, following which the status of infection was determined (group $4 \mathrm{dpi}$ ).

As eels are known to feed little at low temperatures (Tesch 1983) and to maintain uniform experimental conditions the eels of group D4, D9, D 10 and D 19 were starved in this experiment. To elucidate whether Anguillicola crassus were harmed by starving of the host, the results obtained from the eels kept at $19^{\circ} \mathrm{C}$ (group D19) were compared with those from identically treated, but fed, eels (group D19fed). These eels were fed twice a week with pellet food at a rate of $0.7 \mathrm{~g}$ $e^{-1}{ }^{-1}$. Additionally, the eels of group D4/19 were also fed while being kept at $19^{\circ} \mathrm{C}$.

To study the impact of cold water conditions on adult Anguillicola crassus eels were infected with $25 \mathrm{~L}_{3}$ each. To allow the development of the nematodes from the larval to the adult stage all infected eels were first kept at $18^{\circ} \mathrm{C}$. The developmental status of the worms was spot-checked (for number of eels see Fig. 2) from Day 30 p.i. onwards. Thus, it could be concluded that most of the $\mathrm{L}_{3}$ administered to the eels became adult within $80 \mathrm{~d}$ p.i. Subsequently the remaining eels were tion were considered dead and grouped with the decomposed specimens. The presence of $\mathrm{L}_{2}$ (in the egg sheath or emerged) in the swimbladder lumen of the eels was used as proof of the successful reproduction of the nematodes.

Statistical analysis. Data are presented as mean values \pm standard deviation (SD). The data sets of the recovery rate, the percentage of different developmental stages, the percentage of dead Anguillicola crassus and the mean wet weight of the adult worms obtained for the different groups (Table 1) were analysed using the $H$-test (Kruskal-Wallis) and/or the $U$-test (MannWhitney) for significant differences ( $p \leq 0.05$ ).

\section{RESULTS}

\section{Impact of temperature on larval Anguillicola crassus}

The larval development of Anguillicola crassus in the final host showed a clear temperature-dependent pattern. The mean number of $A$. crassus recovered from eel swimbladders at the end of the experiment increased with the water temperature at which the eels were maintained (Fig. 3). The lowest recovery rate, determined for the eels kept $4 \mathrm{~d}$ at $20^{\circ} \mathrm{C}$ and subsequently $115 \mathrm{~d}$ at $4^{\circ} \mathrm{C}$ (group D4, $10.0 \pm 10.1 \%$ ), was nearly the same as the rate obtained from eels kept only $4 \mathrm{~d}$ at $20^{\circ} \mathrm{C}$ (group $4 \mathrm{dpi}, 10.3 \pm 8.8 \%$ ). At all the other temperatures examined significantly higher recovery rates were obtained. Statistical analysis revealed no differences in the recovery rate between group D9 (31.2 $\pm 13.5 \%)$, group D10 (41.9 $\pm 23.9 \%)$ and group D19 $(34.5 \pm 15.8 \%)$. 


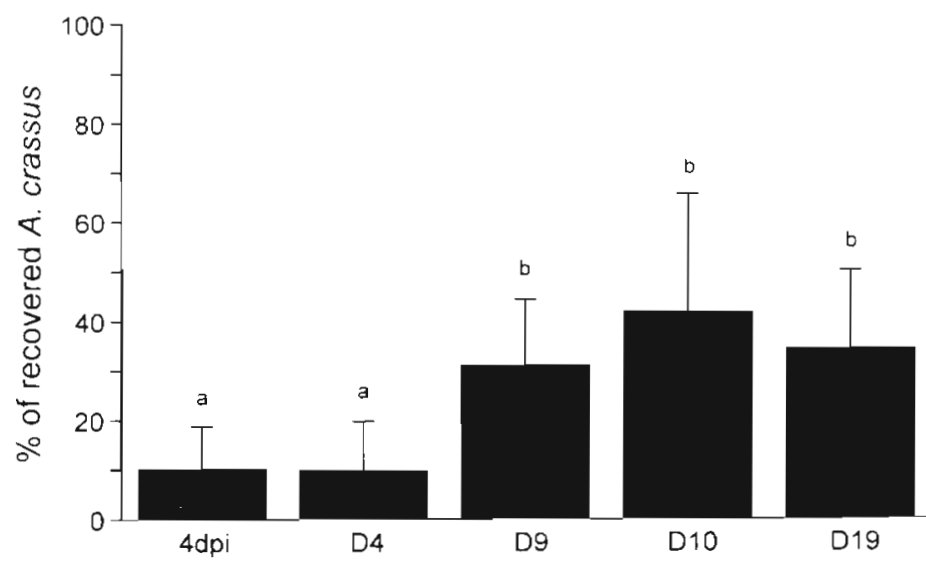

Fig. 3. Anguillicola crassus. Mean percentage recovery of nematodes from the swimhladiter of Anguilla anguilla kept for $4 \mathrm{~d}$ at $20^{\circ} \mathrm{C}(4 \mathrm{dpi})$. $4 \mathrm{~d}$ at $20^{\circ} \mathrm{C}$ and $115 \mathrm{~d}$ at $4^{\circ} \mathrm{C}(\mathrm{D} 4)$, at $9^{\circ} \mathrm{C}$ (D9), and at $10^{\circ} \mathrm{C}$ (D 10$)$ and continuously at $19^{\circ} \mathrm{C}$ (D19). a, b: Groups with a letter in common do not differ significantly at $p \leq 0.05$

Fig. 4 shows the percentage of the different developmental stages of Anguillicola crassus recovered at the end of the experiment. After $4 \mathrm{~d}$ at $20^{\circ} \mathrm{C}$ and $115 \mathrm{~d}$ at $4^{\circ} \mathrm{C}$ (group D4) as well as $4 \mathrm{~d}$ p.i. at $20^{\circ} \mathrm{C}$ (group $4 \mathrm{dpi}$ ) only $L_{3}$, but no $\mathrm{L}_{4}$ or adult worms were found. At $9^{\circ} \mathrm{C}$ (group D9) only a small proportion of worms (5.8 \pm $14.3 \%$ ) had developed to $\mathrm{L}_{4}$. At $10^{\circ} \mathrm{C}$ (group D10) a considerably higher number of the nematodes reached $\mathrm{L}_{4}(41.6 \pm 32.3 \%)$ and even a few adult worms $(0.4 \pm 1.7 \%)$ could be found in the swimbladder lumen. However, $58.0 \pm 31.9 \%$ of $A$. crassus still remained at $\mathrm{L}_{3}$. Finally, at $19^{\circ} \mathrm{C}$ (group $\mathrm{D} 19$ ) the $\mathrm{L}_{3}$ contributed only $1.9 \pm 5.1 \%$, and the $\mathrm{L}_{4} 9.2 \pm 12.2 \%$, to all recovered specimens, whereas $88.9 \pm 14.0 \%$ of the worms had reached the adult stage. In all swimbladders of eels from this group containing mature male and female $A$. crassus $(85.0 \%$ of the examined eels), the successful reproduction of the parasite was manifested by a large number of $L_{2}$ in the swimbladder lumen. The results of the statistical analysis comparing the abundance of the developmen-

Table 2. Anguillicola crassus. Results of the $U$-test ( $p \leq 0.05$ ) comparing the abundance of the developmental stages of the nematode with Anguilla anguilla kept for $4 \mathrm{~d}$ at $20^{\circ} \mathrm{C}$ and $115 \mathrm{~d}$ at $4^{\circ} \mathrm{C}$ (D4), at $9^{\circ} \mathrm{C}$ (D9) and at $10^{\circ} \mathrm{C}$ (D10) and continuously at $19^{\circ} \mathrm{C}$ (D19). s: significantly different; ns: not sig-nificantly different; nd: not determined

\begin{tabular}{|lccc|}
\hline Groups & $\mathrm{L}_{3}$ & $\mathrm{~L}_{4}$ & Adult \\
\hline D4-D9 & $\mathrm{s}$ & $\mathrm{s}$ & nd \\
D9-D10 & $\mathrm{s}$ & $\mathrm{s}$ & $\mathrm{ns}$ \\
D10-D19 & $\mathrm{s}$ & $\mathrm{s}$ & $\mathrm{s}$ \\
\hline
\end{tabular}

tal stages $L_{3}$ and $L_{4}$ and adults, respectively, with the eels maintained at the different temperatures are shown in Table 2 .

If experimentally infected eels which were kept first $4 \mathrm{~d}$ at $20^{\circ} \mathrm{C}$ and subsequently $115 \mathrm{~d}$ at $4^{\circ} \mathrm{C}$ were transferred to $19^{\circ} \mathrm{C}$ (group D4/19), Anguillicola crassus larvae continued their development without being negatively affected (Table 3 ). After $115 \mathrm{~d}$ at $19^{\circ} \mathrm{C}$ the recovery rate was not significantly different from the results obtained from the eels kept continuously for $119 \mathrm{~d}$ at $19^{\circ} \mathrm{C}$ (group D19). In eels that were maintained previously at $4^{\circ} \mathrm{C}$ the percentage of adult worms and their mean wet weight was significantly higher than in eels solely kept at $19^{\circ} \mathrm{C}$

\section{Impact of eel starvation on Anguillicola crassus}

The results obtained from the eels that were fed (group D19fed) compared to those which were starved and kept at nearly the same temperature (group D19) are presented in Table 3. Data analysis revealed no significant difference between the 2 groups with respect to the recovery rate, the percentage of the developmental stages, the wet weight of the adult worms or their reproductivity.

\section{Impact of temperature on adult Anguillicola crassus}

The results from the spot-checked eels kept at $18^{\circ} \mathrm{C}$ are shown in Fig. 2. After $50 \mathrm{~d} \mathrm{p}$.i. the first adults of

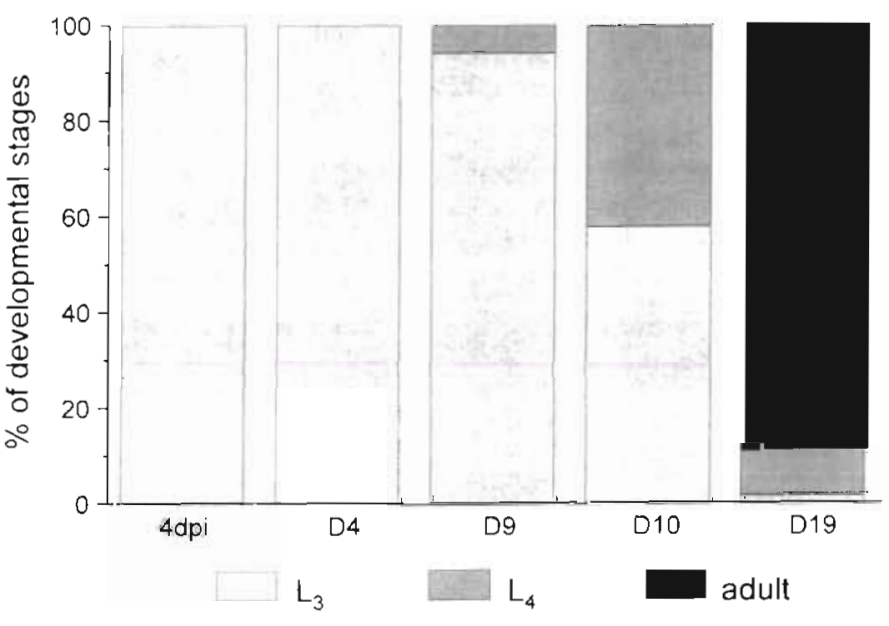

Fig. 4. Anguillicola crassus. Relative percentages of different developmental stages of the nematode out of total number of specimens recovered from the swimbladder of Anguilla anguilla kept for $4 \mathrm{~d}$ at $20^{\circ} \mathrm{C}$ (4dpi), $4 \mathrm{~d}$ at $20^{\circ} \mathrm{C}$ and $115 \mathrm{~d}$ at $4^{\circ} \mathrm{C}$ (D4), at $9^{\circ} \mathrm{C}$ (D9) and at $10^{\circ} \mathrm{C}$ (D10) and continuously at $19^{\circ} \mathrm{C}$ (D19) 
Table 3. Influence of a cold water period and starvation on the development of Anguillicola crassus. The following are given: mean percentage of $A$. crassus recovered from total number of $\mathrm{L}_{3}$ administered, percentages of developmental stages from the recovered specimens, mean wet weight of male and female A. crassus and percentage of Anguilla anguilla containing $\mathrm{L}_{2}$ in the swimbladder lumen. Sample sizes ( $n$ ) are given in parentheses

\begin{tabular}{|c|c|c|c|}
\hline & $\begin{array}{l}\text { Group D19fed } \\
\text { Mean } \pm \text { SD }(n)\end{array}$ & $\begin{array}{c}\text { Group D19 } \\
\text { Mean } \pm \text { SD (n) }\end{array}$ & $\begin{array}{l}\text { Group D4/19 } \\
\text { Mean } \pm \text { SD (n) }\end{array}$ \\
\hline$\%$ recovery & $48.2 \pm 24.3(19)$ & $34.5 \pm 15.8(20)$ & $37.9 \pm 26.4$ \\
\hline$\%$ of $\mathrm{L}_{3}$ & $13.1 \pm 31.2(19)$ & $1.9 \pm 5.1 \quad(20)$ & $0.8 \pm 3.9$ \\
\hline$\%$ of $\mathrm{L}_{4}$ & $2.9 \pm 5.7$ & $9.2 \pm 12.2(20)$ & $1.4 \pm 4.5$ \\
\hline$\%$ of adults & $84.0 \pm 30.8 \quad(19)$ & $88.9 \pm 14.0(20)$ & $97.8 \pm 5.8$ \\
\hline Wet weight of males (mg) & $9.8 \pm 6.5$ & $14.2 \pm 7.6 \quad(18)$ & $17.4 \pm 10.1$ \\
\hline Wet weight of females (mg) & $100.4 \pm 46.7$ & $124.3 \pm 42.3(20)$ & $169.0 \pm 43.7$ \\
\hline$\%$ of eels containing $L_{2}$ & 78.9 & 85.0 & 78.6 \\
\hline
\end{tabular}

Anguillicola crassus appeared in the swimbladder lumen and $67 \%$ of the nematodes had reached $\mathrm{L}_{4}$. At Day 80 p.i. more than $85 \%$ of the worms were adult and from this time on the percentage of adult worms changed only by a small amount. Thus the period of time during which moulting from $\mathrm{L}_{4}$ to adults occurred ranged from 50 to $80 \mathrm{~d}$ at a water temperature of $18^{\circ} \mathrm{C}$.

The impact of the low water temperature on adult Anguillicola crassus became obvious when comparing the data obtained from eels which were kept from Day 81 to Day 185 at $4^{\circ} \mathrm{C}$ (group A4) and $18^{\circ} \mathrm{C}$ (group A18), respectively (Table 4). Although the recovery rates showed no significant differences between the 2 groups, all the other data revealed that adult worms were deleteriously affected by the low temperature. The percentage of dead adult worms and the percentage of larval stages were significantly higher for the eels maintained at $4{ }^{\circ} \mathrm{C}$. Additionally, the mean wet weight of adult $A$. crassus and the number of swim-

Table 4. Impact of water temperature on adult Anguillicola crassus. The following are given: mean percentage of $A$ crassus recovered from total number of $L_{3}$ administered, percentages of developmental stages from the recovered specimens, percentage that were dead, mean wet weight of male and female A.crassus and percentage of Anguilla anguilla containing $\mathrm{L}_{2}$ in the swimbladder lumen. Sample sizes (n) are given in parentheses

\begin{tabular}{|c|c|c|}
\hline & $\begin{array}{c}\text { Group A18 } \\
\text { Mean } \pm \text { SD (n) }\end{array}$ & $\begin{array}{c}\text { Group A4 } 4^{\mathrm{b}} \\
\text { Mean } \pm \mathrm{SD}(\mathrm{n})\end{array}$ \\
\hline$\%$ recovery & $29.8 \pm 26.8(36)$ & $36.4 \pm 25.9$ \\
\hline$\%$ of $\mathrm{L}_{3}$ & $7.7 \pm 19.3(30)$ & $16.2 \pm 16.0$ \\
\hline$\%$ of $\mathrm{L}_{4}$ & $7.3 \pm 18.6(30)$ & $15.7 \pm 11.9(41)$ \\
\hline$\%$ of adults & $85.0 \pm 27.5\{30\}$ & $68.1 \pm 18.6(41)$ \\
\hline$\%$ of dead $A$. crassus & $10.1 \pm 22.2(30)$ & $39.1 \pm 27.5(41)$ \\
\hline Wet weight of males (mg) & $37.2 \pm 19.2(24)$ & $4.7 \pm 8.3$ \\
\hline Wet weight of females (mg) & $187.2 \pm 72.4(24)$ & $16.4 \pm 11.1$ \\
\hline$\%$ of eels containing $\mathrm{L}_{2}$ & $75.0 \quad(36)$ & $8.7 \quad(41)$ \\
\hline
\end{tabular}

bladders containing $\mathrm{L}_{2}$, indicating reproductive activity of adult worms, in eels kept at $4{ }^{\circ} \mathrm{C}$ was approximately 10 times less than the values determined for eels kept at $18^{\circ} \mathrm{C}$.

\section{DISCUSSION}

Development and viability of Anguillicola crassus in the final host were shown to be temperature-dependent. The growth and development of worms did not differ significantly between the starved and fed eels kept at approximately $19^{\circ} \mathrm{C}$. Considering the reduced metabolism of host and parasite at lower temperatures, one can therefore deduce that starvation of the eels over 4 mo at 4,9 or $10^{\circ} \mathrm{C}$ does not affect the nematodes. Results of Polzer \& Taraschewski (1993) revealed that adult worms are able to degrade haemoglobin, which might be sufficient as a nutritive source. Thus, the findings of the present investigation can be attributed exclusively to the impacl of temperature.

The pattern in the relative proportions of developmental stages of Anguillicola crassus after $115 \mathrm{~d}$ at different temperatures can be explained by retarded larval development at lower temperatures. This would be expected, as temperature is known to be an important factor controlling the development of poikilothermic organisms. At about $10^{\circ} \mathrm{C}$, a critical limit appears to be reached as the relatively small rise in temperature from 9 to $10^{\circ} \mathrm{C}$ caused a significant speeding up of larval development.

The results indicate a doubling of the time to the first appearance of 
adult Anguillicola crassus in the swimbladder lumen at $10^{\circ} \mathrm{C}$ compared to $18^{\circ} \mathrm{C}$. A developmental period of approximately $50 \mathrm{~d}$ at $20^{\circ} \mathrm{C}$ as revealed by the spotchecked eels is consistent with the results of Haenen et al. (1996), who observed the first $A$. crassus in the swimbladder lumen $48 \mathrm{~d}$ p.i. at 18 to $20^{\circ} \mathrm{C}$. Nevertheless, at the end of the experiment the relative proportions of developmental stages were highly variable within experimental groups, reflecting individual differences in the specimens

The increased recovery rate at higher temperatures leads to the assumption that not only the duration of development but also the mobility of invading $L_{3}$ is affected by the ambient temperature. This becomes obvious at $4^{\circ} \mathrm{C}$, since after $4 \mathrm{~d}$ at $20^{\circ} \mathrm{C}$ and $115 \mathrm{~d}$ at $4^{\circ} \mathrm{C}$ the number of recovered Anguillicola crassus was as low as after $4 \mathrm{~d}$ at $20^{\circ} \mathrm{C}$. This shows that the $\mathrm{L}_{3}$ do not invade the swimbladder wall simultaneously and also that at $4^{\circ} \mathrm{C}$ they were unable to invade the swimbladder wall at all.

At $4^{\circ} \mathrm{C}$ no sign of larval development could be detected over a period of 4 mo. However, the percentage of adult Anguillicola crassus and their mean wet weight was significantly higher when eels were maintained after the cold spell for a further 4 mo at $19^{\circ} \mathrm{C}$ compared to eels maintained solely for 4 mo at $19^{\circ} \mathrm{C}$. At least 2 hypotheses might explain these findings. It seems possible that the $\mathrm{L}_{3}$ pass a diapause at $4^{\circ} \mathrm{C}$ and further development at increased temperatures is stimulated due to the preceding cold period. On the other hand, development from $\mathrm{L}_{3}$ to $\mathrm{L}_{4}$ might not be entirely stopped but only severely retarded. In this case, one also has to assume a correlation between temperature and larval development. Based on the results obtained from the eels kept at 9 and $18^{\circ} \mathrm{C}$, the time required from infection to the third moult from $\mathrm{L}_{3}$ to $\mathrm{L}_{4}$ at $4^{\circ} \mathrm{C}$ clearly exceeds $115 \mathrm{~d}$. This could explain why no development was observed until Day 11.5 at $4^{\circ} \mathrm{C}$. Although it seems unclear whether larval development continues at $4^{\circ} \mathrm{C}$ or if it is interrupted until the temperature increases again, it can be concluded that a 4 mo period at $4^{\circ} \mathrm{C}$ does not influence the viability of $L_{3}$.

In contrast to the larvae, adult Anguillicola crassus were severely harmed during a $4 \mathrm{mo}$ period at $4^{\circ} \mathrm{C}$. Comparing the nematodes kept at $18^{\circ} \mathrm{C}$ to those kept at $4^{\circ} \mathrm{C}$, the latter showed a significantly lower wet weight. This may reflect a drastically reduced or even arrested metabolism and consequently reduced feeding activity. The 4 times higher number of dead adult worms illustrated the irreversible harm caused by the low temperature. As a result, the reproduction of $A$. crassus was also clearly reduced. The few $\mathrm{L}_{2}$ found in the eels kept at $4^{\circ} \mathrm{C}$ might even have been left over from the period spent at $18^{\circ} \mathrm{C}$. This appears reasonable as free-living $L_{2}$ survive a considerable time at low temperatures (e.g. Kennedy \& Fitch 1990). The small number of dead adult worms found in the eels kept at $18^{\circ} \mathrm{C}$ is considered to reflect common natural conditions, as shown in the field studies of Kennedy \& Fitch (1990) throughout 1 yr.

In summary, the life-cycle of Anguillicola crassus comprises 2 phases in which a sufficiently long period at $4^{\circ} \mathrm{C}$ causes irreversible damage: firstly, $L_{2}$ in the intermediate host (Petter et al. 1989) and, secondly, the adult nematodes in the swimbladder lumen of the final hosts. Generally, a decrease in temperature leads to an increase in time required for a complete life-cycle, probably due to a reduced metabolism of the nematode.

The results presented here together with the facts already known concerning the influence of low temperatures on development in the intermediate host (Petter et al. 1989, 1990) are suitable to explain why Anguillicola crassus in Scandinavia only occurs in anthropogenically heated waters, but not under natural temperature conditions as assumed by Höglund et al. (1992). Our results clearly contradict the hypothesis of Kennedy \& Fitch (1990) that the adults of A. crassus 'appear to be able to survive and reproduce in eels under any conditions that the host can withstand'. Thus, the description of $A$. crassus as a successful coloniser presented by these authors does not apply under cold water conditions. Whilst the temperature regime prevailing in the freshwaters of Central Europe obviously still enables the parasite to build up a stable population, in Scandinavia this might be prevented by an increased mortality of adult worms during the longer winter (with a temperature minimum of $4^{\circ} \mathrm{C}$ in freshwater and even less in the brackish Baltic) and retarded development because of lower temperatures in summer Due to the expected high mortality of adults during long winters, prior to extensive reproduction in early summer gravid specimens must be recruited from the hibernated larvae. A comparison of the water temperatures in southern Swedish lakes (Raab \& Vedin 1995) and Lake Constance, southern Germany (Müller 1983-1994) illustrates the different temperature conditions. In southern Sweden the water temperature exceeds $5^{\circ} \mathrm{C}$ for approximately 7 mo and the $10^{\circ} \mathrm{C}$ threshold for approximately 4 mo per year whereas in South Germany the periods are 10 and 6 mo, respectively. Furthermore, the mean highest summer temperature in the southern Swedish lakes is about $2^{\circ} \mathrm{C}$ lower than that of Lake Constance. However, looking at the data from all areas of Europe where A. crassus occurs (e.g. Canestri-Trotti 1987, Taraschewski et al. 1987, Køie 1991), no influence of latitude on the prevalence or abundance of $A$. crassus is apparent. Such a gradient from northern to southern Europe might be masked by many other factors such as 
the time the parasite has already been in the region, the availability of intermediate and paratenic hosts or the immunological status of the respective eel population. Interestingly, no clear seasonal pattern in infection of eels as a result of the seasonal variation in temperature has been shown so far (Kennedy \& Fitch 1990 Möller et al. 1991, Thomas \& Ollevier 1992, Würtz et al. 1998), although in Japan and Korea a decrease in prevalence during the cold season has been suggested (Egusa et al. 1969, Kim et al. 1989, both cited in Nagasawa 1994). In any case, under field conditions the impact of low winter temperatures on the life-cycle of A. crassus can easily be hidden by the retarded larval development, the longevity of larval stages and delayed mortality of adult worms, as could be concluded from our results.

Concerning North America, where Anguillicola crassus was recently introduced into the southern USA (Johnson et al. 1995, Fries \& Williams 1996), the large Canadian eel populations of the St. Lawrence River or of Newfoundland (Tesch 1983) will in all probability not become infected by the parasite during its northward expansion, due to the low winter temperatures.

Acknowledgements. Thanks are due to Dr B. Hofschulte and Dr D. Stegen who allowed us to use the facility of a cold storage room and to the 'Angelsportverein Karlsruhe' for their support in collecting copepods. We thank C. Haug for her assistance and Dr R. Siddall for revising the English.

\section{LITERATURE CITED}

Blanc G, Bonneau S, Biagianti S, Petter AJ (1992) Description of the larval stages of Anguillicola crassus (Nematoda, Dracunculoidea) using light and scanning electron microscopy. Aquat Living Resour 5:307-318

Canestri-Trotti G (1987) Occurrence of the nematode Anguillicola crassa Kuwahara, Niimi \& Itagaki, 1974 in eels from the Po delta. Italy. Bull Eur Assoc Fish Pathol 7(5):109-111

De Charleroy D, Grisez L, Thomas K, Belpaire C, Ollevier F (1990) The life cycle of Anguillicola crassus. Dis Aquat Org 8:77-84

De Charleroy D, Thomas K, Belpaire C, Ollevier F (1989) The viability of the free living larvae of Anguillicola crassus. J Appl Ichthyol 5:154-156

Fries LT, Williams DJ (1996) Occurrence of Anguillicola crassus, an exotic parasitic swim bladder nematode of eels, in the southeastern United States. Trans Am Fish Soc 125 $794-797$

Haenen OLM, Van Wijngaarden TAM, Borgsteede FHM (1994) An improved method for the production of infective third-stage juveniles of Anguillicola crassus. Aquaculture 123:163-165

Haenen OLM, Van Wijngaarden TAM, Van der Heijden MHT, Höglund J, Cornelissen JBJW, Van Lengoed LAMG, Borgsteede FHM, Van Muiswinkel WB (1996) Effects of experimental infections with different doses of Anguillicola crassus (Nematoda, Dracunculoidea) on European eel (Anguilla anguilla). Aquaculture 141:41-57
Höglund J, Andersson J, Wickström H, Reizenstein M (1992) The distribution of Anguillicola in Sweden and its association with thermal discharge areas. Irish Fish Invest Ser A (Freshwat) 36:143-150

Johnson SK, Fries LT, Willams J, Huffman DG (1995) Presence of the parasitic swim bladder nematode, Anguil licola crassus, in Texas aquaculture. World Aquacult 26 35-36

Kennedy C, Fitch DJ (1990) Colonization, larval survival and epidemiology of the nematode Anguillicola crassus, parasitic in the eel, Anguilla anguilla, in Britain. J Fish Biol 36:117-131

Koie M (1991) Swimbladder nematodes (Anguillicola spp.) and gill monogeneans (Pseudodactylogyrus spp.) parasitic on the European eel (Anguilla anguilla). J Cons Int Explor Mer 47:391-398

Möller H, Holst S, Lüchtenberg H, Petersen F (1991) Infection of eel Anguilla anguilla from the River Elbe estuary with two nematodes, Anguillicola crassus and Pseudoterranova decipiens. Dis Aquat Org 11:193-199

Moravec F (1992) Spreading of the nematode Anguillicola crassus (Dracunculoidea) among eel populations in Europe. Folia Parasitol 39:247-248

Müller H (1983-1994) Jahresbericht der Internationalen Gewässerschutzkomission für den Bodensee: Limnologischer Zustand des Bodensees. Karlsruhe, p 7-20

Nagasawa K, Kim YG, Hirose H (1994) Anguillicola crassus and Anguillicola globiceps (Nematoda: Dracunculoidea) parasitic in the swimbladder of eels (Anguilla japonica and $A$. anguilla) in East Asia. Folia Parasitol 41:127-137

Neumann W (1985) Schwimmblasenparasit Anguillicola bei Aalen. Fischer \& Teichwirt 11:322

Petter AJ, Cassone J, Le Belle N (1990) Observations sur la biologie des premiers stades larvaires d'Anguillicola crassus, nématode parasite d'anguille. Ann Parasitol Hum Comp 65:28-31

Petter AJ, Fontaine YA, Le Belle N (1989) Étude du dévelopement larvaire de Anguillicola crassus (Dracunculoidea Nematoda) chez un cyclopidae de la région parisienne. Ann Parasitol Hum Comp 64:347-355

Polzer M, Taraschewski H (1993) Identification and characterization of the proteolytic enzymes in the developmental stages of the eel-pathogenic nematode Anguillicola crassus. Parasitol Res 79:24-27

Raab B, Vedin H (1995) National atlas of Sweden, Climate lakes and rivers. Almqvist \& Wiksell International, Stockholm

Taraschewski H, Moravec F, Lamah T, Anders K (1987) Distribution and morphology of two helminths recently introduced into European ee populations: Anguillicola crassus (Nematoda, Dracunculoidea) and Paratenuisentis ambiguus (Acanthocephala, Tenuisentidae). Dis Aquat Org 3: $167-176$

Tesch FW (1983) Der Aal, Biologie und Fischerei. Paul Parey, Hamburg

Thomas K, Ollevier F (1992) Population biology of Anguillicola crassus in the final host Anguilla anguilla. Dis Aquat Org 14:163-170

Thomas K, Ollevier F (1993) Hatching, survival, activity and penetration efficiency of second-stage larvae of Anguillicola crassus (Nematoda). Parasitology 107:211-217

Würtz J, Knopf K, Taraschewski H (1998) Distribution and prevalence of Anguillicola crassus (Nematoda) in eels Anguilla anguilla of the rivers Rhine and Naab, Germany. Dis Aquat Org 32:137-143

Submitted: December 1, 1997; Accepted: March 5, 1998

Proofs received from author(s): May 26, 1998 